H A R VAR D

\title{
Securing Jobs or the New Protectionism?: Taxing the Overseas Activities of Multinational Firms
}

Mihir A. Desai

\section{Working Paper}

09-107 


\title{
Securing Jobs or the New Protectionism?: Taxing the Overseas Activities of Multinational Firms
}

\author{
Mihir A. Desai* \\ Harvard University and NBER
}

\begin{abstract}
Tax policy toward American multinational firms would appear to be approaching a crossroads. The presumed linkages between domestic employment conditions and the growth of foreign operations by American firms have led to calls for increased taxation on foreign operations - the so-called "end to tax breaks for companies that ship our jobs overseas." At the same time, the current tax regime employed by the U.S. is being abandoned by the two remaining large capital exporters - the UK and Japan - that had maintained similar regimes. The conundrum facing policymakers is how to reconcile mounting pressures for increased tax burdens on foreign activity with the increasing exceptionalism of American policy. This paper address these questions by analyzing the available evidence on two related claims - i) that the current U.S. policy of deferring taxation of foreign profits represents a subsidy to American firms and ii) that activity abroad by multinational firms represents the displacement of activity that would have otherwise been undertaken at home. These two tempting claims are found to have limited, if any, systematic support. Instead, modern welfare norms that capture the nature of multinational firm activity recommend a move toward not taxing the foreign activities of American firms, rather than taxing them more heavily. Similarly, the weight of the empirical evidence is that foreign activity is a complement, rather than a substitute, for domestic activity. Much as the formulation of trade policy requires resisting the tempting logic of protectionism, the appropriate taxation of multinational firms requires a similar fortitude.
\end{abstract}

* mdesai@hbs.edu. Thanks to Nihar Shah and Kathleen Luchs for excellent research assistance, Alan Auerbach and other participants at the ITPF-Tax Policy Center Conference on American Tax Exceptionalism for very helpful comments, and the Division of Research at Harvard Business School for generous funding. Correspondence and conversations with Davin Chor, Ken Scheve and Stephen Yeaple were particularly helpful. 


\section{Introduction}

The last two decades have witnessed two significant economic developments that are often linked in the popular imagination - the rapid escalation of the foreign activities of American multinational firms and rising levels of economic insecurity, particularly amongst workers in certain sectors. The underlying trends of concern are summarized in Figure 1. First, the value of the claims held by U.S. multinational firms abroad is depicted by the direct investment position line that reached nearly $\$ 3$ trillion by 2007 . Notably, the direct investment position has more than tripled since 1997. The rise in the net income abroad of U.S. multinationals is even more dramatic with net income abroad reaching $\$ 350$ billion in 2007. At the same time, domestic employment in manufacturing has undergone an equally dramatic set of changes with employment declining in a rapid fashion particularly after 1997, just as U.S. multinational firms were rapidly escalating their foreign activities. It is unsurprising that these phenomena have become linked in the popular imagination such that foreign activity would appear to be displacing domestic activity.

One consequence of this linkage is the deep skepticism of Americans toward outbound foreign direct investment. As noted in Scheve and Slaughter (2006, p. 224), "a consistent plurality to majority [of Americans] think that FDI in both directions eliminates jobs.... with the prominent concern that outward FDI entails US firms 'exporting' jobs outside the country. Over two-thirds of Americans think that 'companies sending jobs overseas' is a 'major reason' for 'why the economy is not doing better than it is." While this summary relates to polling results from the late 1990s, more recent polling results on this question, displayed in Figure $2 \mathrm{a}$, suggest that these feelings have heightened. Figure $2 \mathrm{~b}$ also suggests that the populace is unhappy with historic policies on this dimension and expect that ready solutions are available to them through policymaking. Unsurprisingly, policymakers have begun to respond to these trends and perceptions by arguing for penalties on foreign activities or subsidies for domestic activity by American firms. Finally, 
dramatic estimates of future "potential job losses" created by further international engagement by American firms have only further amplified these sentiments. ${ }^{1}$ Increasingly, the overseas activities of multinational firms have become a source of concern for domestic employment in a manner that parallels historic attitudes toward trade.

The presumed linkages between these phenomena have led many to call for a reconsideration of the appropriate policy response to the rising level of global engagement by American multinational firms. The tax treatment of foreign investment has received particular attention. The current system of taxing the foreign activities of American firms - a worldwide regime with limited foreign tax credits and deferral until profits are repatriated - is often characterized as providing a subsidy for firms to invest abroad, deepening the impression that these policies deserve reconsideration. To many, increasing the tax burden on outbound investment by American multinational firms offers the promise of alleviating domestic employment losses and insecurity while also raising considerable revenue. This sentiment is typically manifest in the powerful political formulation of "ending tax breaks for companies that ship our jobs overseas."

Given that these causal linkages are becoming cemented in the popular imagination, it is useful to investigate the merits of these claims. Evaluating these claims and formulating an appropriate policy response requires an exploration of two related questions. First, from a theoretical perspective, it is critical that the economic determinants of outbound investment decisions be understood. Alternative characterizations of the nature of these investment decisions lead to very distinct policy prescriptions. Second, from an empirical perspective, it is important to synthesize what is known about the relationship between domestic and foreign activities. Any such

\footnotetext{
${ }^{1}$ See, for example, Blinder (2006).
} 
empirical effort must begin by looking beneath these aggregate trends and by attempting to address the thorny question of causality.

Sections 2 and 3 of this paper address these two questions by reviewing extant theoretical and empirical work. Fortunately, recent advances on both questions serve to illuminate the validity of alternative perspectives on the appropriate tax policy toward multinational firms. Section 4 of the paper reviews the recent American experience in some more detail to further address the validity of these linkages. Section 5 concludes with some implications for how policy prescriptions can be informed by this research.

\section{Why do firms invest abroad?}

Discussions of the appropriate tax policy for multinationals firms often neglect the motivations of firms for investing abroad. Without an understanding of these motivations, it is impossible to articulate meaningful policy responses, much as it would be meaningless to consider the merits of income taxes versus consumption taxes without understanding labor-leisure and intertemporal tradeoffs. Research on the motivations of multinational firms extends back to the 1950s and has resulted in three distinct waves of thinking, each yielding a distinct set of policy prescriptions. Indeed, a given policy prescription can be evaluated by the degree to which it corresponds to a credible explanation of firm motivations.

\section{A. Arbitrage}

First, and most influentially for policy purposes, firms can be understood to be arbitraging rate of return differentials across countries. This arbitrageur view of multinational firms interprets FDI decisions as being motivated by the prospect of a higher pretax return abroad and the resultant capital flows as eliminating any return discrepancies. The arbitrageur view also implicitly views multinational firms as being the vehicle through which capital is transferred from one country to another. Unsurprisingly, this view was dominant in the immediate post-war era where the 
central problem appeared to be how a social-planner/super-power might optimally design rules to assure that its capital would arrive in the appropriate destination.

The arbitrageur view has clear implications for the optimal design of tax policies toward FDI. Worldwide welfare is maximized by making sure that these arbitrageurs allocate capital around the world in a way they would have in the absence of taxes, to ensure that aggregate worldwide returns are maximized. As formulated in Musgrave (1969) into the welfare norm known as capital export neutrality (CEN), this requires the granting of unlimited foreign tax credits to ensure that firms face the same tax rate - the home rate - wherever they invest. If a more parochial approach is desired such that only national welfare is maximized, then the only change required is an alternative treatment of foreign taxes paid (via a deduction rather than a credit) as taxes paid to foreign governments are unimportant for national welfare.

The arbitrageur view has proven remarkably influential and resilient in the policy-making domain. The patchwork of American tax policy toward foreign income may seem incomprehensible but can be best understood as a set of real-world accommodations to the prescriptions embodied by the arbitrageur view. First, unlimited foreign tax credits can lead to undesirable incentives for foreign governments leading to the limitation of foreign tax credits to the U.S. statutory rate. The tax burden created by this limitation is offset by the benefits of deferral until earnings are repatriated. Finally, some fraction of expenses incurred domestically must be allocated abroad to prevent an undue incentive to invest abroad beyond the merits of the pretax return. ${ }^{2}$

The arbitrageur view and the policy prescriptions that emerge from it remain the dominant paradigm for understanding foreign activity by American firms. The primacy of the arbitrageur view in the policy domain is perhaps best exemplified by the common characterization of the exemption

\footnotetext{
2 This rationalization of U.S. policy may be overly generous to the current policy. Indeed, it is hard to find a rationale for source-based taxation in the optimal tax literature and CEN is best understood as a tool to evaluate policy conditional on the existence of source-based taxation.
} 
of foreign income as a "subsidy" to investing abroad. If firms are arbitrageurs, then exemption of foreign income provides them an incentive to invest beyond a point merited by pretax returns. Simiarly, under the arbitrage view, deferral of taxation until foreign profits are repatriated also represents a "subsidy" to investing abroad. Finally, the arbitrage view also provides the foundation for linking increased investment abroad with decreased domestic investment. If firms are arbitraging returns around the world, then, by definition, capital invested abroad represents capital that is not being invested domestically.

Prior to assessing the relevance of the arbitrage view, it is useful to note how distinct Musgrave's simple tax policy prescriptions are from other analysts who also employed the arbitrage view. In international trade theory, a rich line of inquiry developed simultaneous with Musgrave's work that emphasized just how difficult it was to arrive at definitive policy prescriptions on taxing capital outflows. Specifically, Kemp (1966), initially, and Jones (1967), most extensively, clarified that it is incorrect to separately analyze taxes on capital flows that are arbitraging rate of return differentials from trade policy more generally given various interactions. In this line of work, results are highly variable but it is worth noting that situations arise where either taxing or subsidizing capital outflows is welfare enhancing depending on the relative capital intensity of a country and the degree of economic specialization in countries. As such, the arbitrage view and the policy prescriptions that emerge from it are not nearly as clear as the Musgrave perspective suggests.

While the influence of the arbitrageur view has lasted for decades in the policy domain, it prevailed for a very short period amongst scholars of multinational firms. Dissatisfaction with the arbitrage view sprang from two primary sources. ${ }^{3}$ First, it does not appear that firms respond to rate of return differentials. Indeed, the "Lucas paradox" outlined in Lucas (1990) is that capital of ${ }^{3}$ See Gordon and Hines (2002) and Hines (2008) for a fuller discussions of the limitations of the Musgrave framework. 
all types does not seem to flow where rates of return would appear to be high. More specifically, patterns of multinational firm activity would suggest that firms are particularly uninterested in rate of return differentials as firms from developed countries mostly invest in other developed countries, between which rate of return differentials are thought to be small, rather than in developing countries. Similarly, the dominant form of multinational activity is the acquisition of existing assets and most multinational firm activity is in high-technology sectors. ${ }^{4}$ These patterns do not support the notion that rate of return differentials are motivating firm investment. Second, the arbitrage view has a limited role for firms. Firms only exist to channel capital abroad in this view. There is nothing that distinguishes multinational firms from other investors and, as such, this would seem to abstract from some critical differences between investors and firms. Most importantly, firms have begun changing their national identity for various purposes - decentering themselves from any one particular country - in a way that is not imagined by the proponents of the arbitrage view. ${ }^{5}$

The policy prescriptions that emerge from the arbitrage view also have the undesirable feature of describing little, if any, of real world policies outside of the U.S. Within the arbitrage view, nations interested in pursuing their own interests should employ worldwide regimes with deductions for foreign taxes paid, a system that is not found anywhere in the world. Instead, the dominant approach to taxing foreign income around the world now appears to be exemption of foreign source income, which is a policy prescription that the arbitrage view specifically argues against. For these reasons, the arbitrage view of multinational firm activity, despite its policy influence in the U.S., does not correspond to a modern understanding of firm activity or to the policy approaches of countries other than the U.S.

\footnotetext{
${ }^{4}$ See Barba-Navaretti et al. (2004) for a discussion of these patterns.

${ }^{5}$ See Desai (2009) for a discussion of these changes to the national identity of firms.
} 
Finally, as described above, the arbitrage view presumes that firms serve to channel capital from home to abroad and the presumption of displaced domestic activity rests on this idea as well. It is useful to conclude this section with a review of the changing forms of foreign investment by Americans, as shown in Figure 3. Until 1992, multinational firms were the primary means of international investment by Americans, often by a large margin. More recently, direct holdings of foreign securities have become the dominant means of gaining foreign exposure, now by a fair margin. As such, the arbitrage view of multinational firm investing may have accurately characterized a dominant motivation for these investments through the 1980s. With significantly decreased barriers to foreign portfolio investment, however, this characterization of firm investment decision making appears to be considerably more tenuous. Said another way, it is hard to know why multinational firms would serve as a dominant means of arbitraging rates of return when so many alternative instruments now exist to accomplish such arbitrage more efficiently.

\section{B. Firm-specific advantages 6}

The dominant view of why firms invest abroad amongst scholars who study multinational firms is that these investments represent efforts to exploit a firm-specific advantage. In contrast to the arbitrage view, these scholars view FDI as arising from differential capabilities and, consequently, productivity amongst firms and the extension of intangible assets across borders. This intuition squares well with the empirical patterns of FDI which include the fact that much FDI happens between rich countries and that much of what we consider FDI are transfers of control and ownership and need not involve transfers of net savings.

This emphasis on transfers of ownership and the productivity differences that drive ownership patterns yields distinctive optimality conditions from the traditional ones articulated

\footnotetext{
${ }^{6}$ This section draws on Desai and Hines $(2003,2004)$.
} 
above. In addition, this characterization of FDI as arising from differential productivity and resulting changes in ownership also raises the possibility that outbound FDI need not be associated with less investment domestically. Indeed, it is conceivable that outbound FDI is associated with additional investment at home by the multinational or with additional investment by foreign firms in the U.S. Under this view, in short, multinational firms are not engaged in the reallocation of the capital stock as much as they are engaged in the reallocation of ownership and control of existing capital stocks.

This emphasis on ownership suggests that tax rules should be evaluated by the degree to which they ensure that the identities of capital owners are unaffected by tax rate differences, thereby permitting the market to allocate ownership rights to where they are most productive. This perspective yields the welfare benchmarks of capital ownership neutrality (CON) and national ownership neutrality (NON). CON demands that tax rules do not distort ownership patterns and can be achieved with exemption as the owner with the highest reservation price (and greatest productivity) owns the asset. More generally, CON can be consistent with foreign tax credit systems as again such systems allow, under certain conditions, that owners with higher productivity levels own the appropriate assets. With so few countries employing worldwide regimes today, such conditions are likely not to be operative and CON is consistent with a move to exemption in today's environment.

Finally, NON suggests, much as is evident in practice in the world, that countries designing tax rules in their own narrow interest will exempt foreign income. These recommendations arise in a world where only ownership claims are being distorted by tax incentives as outbound FDI is either associated with a commensurate rise in domestic investment or by inbound FDI. When both capital stocks and ownership claims are impacted by tax rules, the CON/NON framework provides intermediate recommendations. 
The CON/NON framework places productivity differences amongst multinational owners and the transfers of control induced by tax rules front and center in analyzing the efficiency of tax rules. The relevance of such a framework depends on the degree to which such differences matter relative to the actual transfers of net saving emphasized in the CEN framework. That scholars who study multinationals have dismissed the view of FDI as transfers of net savings as "neither satisfying theoretically nor confirmed empirically" suggests that employing welfare frameworks that rely exclusively on such notions is incomplete at best. ${ }^{7}$ That incorporation of the considerations that such scholars emphasize yields rules that are actually employed further suggests the importance of these alternative frameworks.

Finally, it should be noted that the CON/NON framework undercuts the idea that deferral in a foreign tax credit system or the move to exemption is an inappropriate "subsidy" to foreign activity. Rather, the CON/NON framework suggests that current American tax policy is punitive relative to a welfare-maximizing policy and that preservation of deferral or the transition to exemption represents movement toward a more enlightened policy.

\section{C. Systematic variability in productivity}

While the previous wave of scholarship on multinational firms emphasized firm-specific advantages and the possibility of heterogeneity in productivity, a more recent wave emphasizes that the variability in productivity is systematic and linked to the foreign exposure of firms. Productivity across firms within relatively narrow industry classifications has been shown to vary by remarkable degrees. Bernard et al. (2003) show that one standard deviation from mean levels of industry productivity can mean a $75 \%$ change in productivity. These differences have now been shown to be related to international exposure - Bernard et al. (2006) show that exporting firms are fourteen percent more productive than non exporters. These effects have also shown to precede

\footnotetext{
${ }^{7}$ See Caves (1996).
} 
the exporting decisions suggesting that causality does not run the other way. Similarly, Tomiura (2007) and Helpman et al. (2004) show that multinational firms are more productive than nonmultinational exporters by a similar margin. Moreover, Yeaple (2008) shows that these productivity differences are also present within multinational firms and productivity varies systematically with how large a firm's foreign operations are.

This fairly strict "hierarchy" of productivity is now well established and corresponds to models with reasonable assumptions (Melitz (2003) and Bernard et al (2003)). This literature also has implications for barriers to trade. In Bernard (2006), it is shown that trade liberalizations reallocate production across firms toward more productive firms raising aggregate productivity and welfare. In short, this literature suggests that policies can reallocate production across firms and have important welfare consequences in the process.

The applications of this logic to the debate on the taxation of multinational firms can be sketched here via analogy to other costs present in these models, though it has yet to be worked out fully. ${ }^{8}$ Taxes on foreign profits of firms limit the number of firms who do FDI, and production is reallocated away from the most productive firms as weaker firms survive in the home market given the tax (entry is reduced because of the tax also). Overall welfare is reduced at home given the lowered competition amongst firms. Abroad, more foreign firms enter and foreign firms now enter the home market with their highest productivity firms. Taken together, the tax on the foreign operations of firms of one country reduces the welfare in that country by making competition amongst firms softer and by reallocating production away from the most productive firms. ${ }^{9}$

This new evidence on the systematic link between firm productivity and foreign exposure provides a new dimension to the consequences of taxing multinational firms. While the firm-

\footnotetext{
${ }^{8}$ Many thanks to Stephen Yeaple for his help in clarifying this.

${ }^{9}$ See Chor (forthcoming) and Demidova and Rodriguez-Clare (2007) for a similar analysis but of subsidies for FDI.
} 
specific advantages view identifies the loss of productivity from reallocating ownership, this new evidence makes it clear that the losses will be large given the variability in productivity. Additionally, this perspective suggests that there are further welfare consequences by changing the nature of competition amongst firms that ripple through to consumer welfare. This brief sketch suggests that further explorations of the application of these models to the question of taxing foreign profits would be highly profitable. ${ }^{10}$

\section{Is foreign activity lost domestic activity?}

As with the theoretical work, empirical work on the relationship between foreign and domestic activity began by taking a macroesque approach that studied the correlations of outflows of foreign direct investment and domestic investment. Feldstein (1995) analyzes decade-long averages of aggregate FDI and domestic investment in OECD economies, reporting evidence that direct investment abroad reduces domestic investment levels. Devereux and Freeman (1995) come to a different conclusion in their study of bilateral flows of aggregate investment funds between seven OECD countries, finding no evidence of tax-induced substitution between domestic and foreign investment, and Desai, Foley and Hines (2005a) report time series evidence that foreign and domestic investment are positively correlated in the U.S.. Unsurprisingly, work investigating level of capital flows comes to mixed results and more recent work has emphasized firm level analyses.

Firm-level analysis holds considerable promise but must grapple with thorny identification issues. Simple comparisons of domestic and multinational firms or of the domestic and foreign operations of a given multinational firm face varied problems. Specifically, domestic and multinational firms may differ in unobservable ways and the domestic and foreign operations of a

\footnotetext{
${ }^{10}$ Davies and Eckel (2009) provide one such effort that emphasizes tax competition but they do not specifically consider the effects of taxing overseas profits.
} 
given multinational firm are likely responding to common factors. Empirical work in this area has attempted to address these difficulties by aggregating firm-level data to the industry level, applying state-of-art matching methods for comparing domestic and multinational firms, and by instrumenting for plausibly exogenous changes to the foreign operations of multinational firms.

Arndt, Buch and Schnitzer (2007) employ detailed firm-level data from Germany to study if investment levels are complementary at the industry level. Arndt et al. argue that multinational firms are characterized by linkages to other firms so that the relevant analysis must incorporate these linkages - accordingly, they aggregate their firm level data to the industry level. Their conclusion is that outbound FDI has a positive effect on the domestic capital stock, both for capital owned by domestic firms and for inward FDI. Interestingly, these results are strongest for industries where multinational firms are dominant and for those where FDI is motivated by seeking market access. For industries where cost consideration may dominate in motivating FDI, they find no relationship at the industry level.

Across Europe, firm level studies have found a positive association of foreign expansions and domestic employment, using fairly rigorous matching procedures to identify the effect of going abroad. Barba Navaretti and Castellani (2003), Hijzen et al. (2006), and Kleinert and Toubal (2006) all find no negative effects on employment domestically of the decision by Italian, French and German firms, respectively, to initiate production abroad. Indeed, all papers report a significant and positive effect on productivity and on employment of the decision to become multinational. Egger and Pfaffermayr (2003) identify some possible channels for this by demonstrating that, for Austrian firms, investing abroad has a positive impact on investment in intangible assets and on R\&D. European work has also shed light on the degree to which investments in developing versus developed countries have distinctive effects. Barba Navaretti et 
al. (2006), using French and Italian data, find no evidence of distinctive impacts of locating production abroad in developing or developed markets.

The fear of job loss stemming from offshoring has been christened "kudoka" in Japan. Ando and Kimura (2007) suggest that the domestic employment losses that generate these concerns have not been driven by firms that expanding abroad. They report that Japanese firms increasing their overseas activity increase domestic employment at rates that are three to eight percent greater than comparable purely domestic firms. These effects are most pronounced in manufacturing industries and are accompanied by significant relative increases in intrafirm trade as firms expand abroad.

In contrast to other studies, Desai, Foley and Hines (2009) employ an instrumental variables approach, as opposed to matching procedures, to study the effects of the foreign operations of American manufacturing firms on their domestic operations. The simple correlation of changes in foreign and domestic activity is evident from Figure 4 which is taken from their paper. This figure presents a scatter plot of foreign and domestic sales growth rates for multinational firms in the sample. The upward sloping relationship between foreign and domestic sales growth in Figure 4 suggests a positive correlation between growth rates of foreign and domestic economic activity. Given the possibility of unobserved variables that drive both foreign and domestic growth, a suitable instrument that influences foreign operations only holds the promise of identifying this effect more cleanly. Instrumenting for changes in foreign operations with GDP growth rates of the foreign countries in which they invest provides estimates that indicate that 10\% greater foreign investment is associated with $2.6 \%$ greater domestic investment, and $10 \%$ greater foreign employee compensation is associated with $3.7 \%$ greater domestic employee compensation.

Several studies do find some negative impacts of outbound FDI on source countries. In particular, Brainard and Riker (1997, 2001), Muendler and Becker (2006), Simpson (2008) and 
Harrison and McMillan (2007) all report similar results. These results are characterized by two features, that are exemplified by the Harrison and McMillan paper. First, they attempt to discriminate on the basis of the motivation for multinational firm expansions between horizontal FDI (firms producing the same good in different locations) and vertical FDI (firms that locate different aspects of production in different locations). Harrison and McMillan (2007) use firm-level data from the U.S. and identify, as do these other studies, complementarity in vertical FDI and substitutability in horizontal FDI. Second, the substitutability effects for horizontal FDI are, in the Harrison and McMillan paper and in others, "very small" with very large wage differences in host countries contributing to minimal employment impacts at home. Nonetheless, these studies do find some evidence of substitutability in horizontal FDI. In assessing the importance of these results, it is useful to note that the relative importance of vertical FDI appears to have been underestimated by a fair margin (see Alfaro and Charlton (forthcoming)) and is now thought to dominate horizontal FDI as the primary form of FDI. ${ }^{11}$

Taken together, it is hard to find systematic evidence of significant negative impacts of the overseas activities of firms on domestic investment or employment. Indeed, the emerging consensus is that the average effect is positive, though it may mask some underlying heterogeneity. Given the dramatic growth in foreign operations by multinational firms over the last fifteen years and the similarly marked changes in employment structures in many countries during this period, the inability to find any systematic evidence using firm-level evidence is suggestive that other factors - e.g. falling prices of investment goods, trade patterns - have driven the employment changes that are so worrisome.

\footnotetext{
11 See Hanson, Mataloni and Slaughter $(2001,2005)$, Yeaple (2003) and Bernard, Jensen, and Schott (2006) for the importance of vertical FDI relative to horizontal FDI.
} 
This evidence also informs the debate over which welfare norm - CEN or CON - is more applicable for evaluating tax policy. The absence of systematic evidence on substitutability undercuts the arbitrage view of multinational firms where capital is invested in one of two locations and the tax policy prescriptions that emerge from it. Similarly, this evidence provides some comfort to the notion embedded in $\mathrm{CON}$ - that it is appropriate to emphasize productivity differences rather than capital movements in evaluating tax policy.

\section{The recent U.S. experience}

While the econometric, firm-based evidence described above is compelling to some, the aggregate picture depicting the dramatic decline in manufacturing employment in a period coincident with rapid growth abroad by American firms still may motivate skepticism of foreign activity and the policy prescription that taxes on foreign activity should be increased. Accordingly, it is worth examining this recent experience further to determine if such a link is robust to some further exploration.

The two panels of Figure 5 describe the evolution of several measures of domestic (U.S. parents) and foreign (Affiliates) activity for all U.S. multinational firms and the subset of those engaged in manufacturing from 1982 to 2006. Several impressions emerge from these descriptive figures. For the panel analyzing all industries, the sales and assets measures indicate comparable growth trajectories for domestic and foreign operations. For net income, the picture is more mixed with domestic net income appearing much more volatile than foreign income and foreign income growing particularly strongly in the last five years. In contrast, employee compensation appears to have grown more rapidly domestically than abroad. Finally, and most importantly for many, employment domestically and abroad follow similar trends but domestic employment declines in the early 2000s before retaining its upward trend after 2002. 
The panel depicting these patterns for the manufacturing industries is similar in many respects but is sharply different with respect to employment. The bottom right frame of Figure 5 seems to manifest precisely the concern over substitution between domestic and foreign employment. Specifically, domestic manufacturing employment drops through much of the last twenty five years and particularly so during the early 2000s while foreign manufacturing employment by American firms steadily rises throughout the period. This evidence is what underlies the sentiment that current tax policy on foreign activities may be unduly generous given the loss (growth) of jobs domestically (abroad).

Such an interpretation ignores the performance of multinational firms relative to purely domestic firms. For a fuller appreciation of the role of multinational firms in the domestic economy, it is useful to consider the share of employment that is accounted for by the domestic operations of U.S. multinational firms. Figure 6 provides two ratios - the ratio of domestic employment of all U.S. multinational firms to total private employment in the U.S. and the ratio of domestic employment by U.S. multinational manufacturing firms to total domestic manufacturing employment. For all industries, this ratio declines from the early 1980s to the early 1990s and then features a leveling off for much of the remaining period at around 20 percent.

For the manufacturing series in Figure 6, a similar decline characterizes the initial half of the sample. The "shake-out" in manufacturing employment in the late 1990s and early 2000s that is visible in Figure 1, however, has been accompanied by a fairly significant increase in the relative share of multinational firms in the domestic employment base from 49 percent in 1998 to 56 percent in 2003 before declining to 54 percent in 2006. In light of the theories discussed above, the rapid decline of manufacturing employment in the late 1990s and early 2000s might well best be understood as marking the exit of purely domestic, low-productivity players rather than the 
displacement of domestic activity abroad by multinational firms. Scratching slightly below the surface of Figure 1 suggests a dynamic that is quite different from the inference made by most.

Finally, another way to illuminate these concerns is to try and understand the relative use of skilled labor domestically and abroad as this may indicate how American multinational firms trade off wage differentials in their investment decisions. Figure 7 analyzes the degree to which skilled labor is disproportionately used domestically or abroad, by industry. Unfortunately, a limited times series is available for this figure, limiting any inference on how this ratio has changed over time. Figure 7 is notable for several features. First, it is striking that across all industries the share of skilled labor employed domestically and abroad is roughly the same. Second, there does not appear to be any significant, systematic change from 2004 to 2006 in the use of skilled labor at home or abroad. Finally, there is heterogeneity across industries with some industries - including manufacturing - featuring higher ratios of skilled labor domestically than abroad. Even these differences, though, appear relatively small. If the concern is that certain types of jobs are being exported overseas, one might expect considerably more significant difference and a more worrisome trend than is apparent in Figure 7.

These descriptive figures are far from decisive. For those skeptical of the econometric evidence presented in section III, however, it is useful to note that some simple and pervasive intuitions are not manifest in the aggregate data. Growth on many dimensions at home and abroad is comparable for multinational firms and is more rapid at home on some dimensions. Within manufacturing employment, the apparent trends that are worrisome should properly be interpreted as the outperformance (with respect to employment) of multinational firms relative to domestic firms in response, presumably, to significant changes in the global market and to changed prices in production goods. Finally, the skill composition of employment abroad is not altogether different than the skill composition of employment domestically. Neither descriptive nor sophisticated 
econometric evidence is supportive of the intuition of foreign activity motivated by, or having the effect of, substituting for domestic activity.

\section{Tax Policy Implications}

Tax policy toward multinational firms would appear to be approaching a crossroads. The presumed linkages between domestic employment conditions and the growth of foreign operations by American firms have led to calls for increased taxation on foreign operations. This could take the form of a repeal of deferral or a move to a formula apportionment system. At the same time, the current regime employed by the U.S. is being abandoned by the two remaining large capital exporters - the UK and Japan - that had maintained similar regimes. ${ }^{12}$ As such, current American tax policy appears increasingly more onerous relative to policies employed by other countries. The conundrum facing policymakers is how to reconcile mounting pressures for increased tax burdens on foreign activity with the increasing exceptionalism of American policy.

The resolution of this conundrum may lie in a reconceptualization of what multinational firms do. The recommendation of increased tax burdens on foreign activity corresponds exclusively to the notion of firms as arbitrageurs. While this view had merits when the U.S. was the largest capital exporter in the world and when alternative instruments for worldwide arbitrage were limited, it increasingly appears out of step with modern theories of firm behavior. Similarly, it appears that there is little systematic evidence to support the depiction of the relationship between foreign and domestic activity that naturally grows out of the arbitrage view - that foreign activity by multinational firms displaces domestic economic activity. The resonant experience of the manufacturing shake-out of the last decade also does not support the intuition of displacement.

The abandonment of the arbitrage view for a firm-specific advantages view allows for an easy understanding of the empirical evidence that foreign activity is complementary to domestic

${ }^{12}$ See HMRC (2008) and PWC (2008) for a discussion of changes afoot in the UK and Japan, respectively. 
activity. Similarly, a firm-specific advantages view, along with an appreciation for the correlation between productivity levels and foreign engagement, can help explain why the recent manufacturing shakeout featured an increase in the relative importance of American multinational firms in the U.S. economy. Finally, the firm-specific advantages view, as embodied by the NON norm, also explains why countries, in their own interest, have abandoned worldwide tax regimes and opted for an exemption approach toward taxing foreign activity.

The required reconceptualization for policymakers is one that couples the prospects of American firms abroad with their prospects at home - a view that springs naturally from the firmspecific advantages view. While such a formulation resists the easy logic of substitutability between foreign and domestic operations of multinationals, it appears to be the formulation which many countries, including the UK and Canada ${ }^{13}$, have relied upon in revising their policies and has the added virtue of having considerable empirical support. Much as the formulation of trade policy requires resisting the tempting logic of protectionism, decisions on the appropriate taxation of multinational firms require a similar fortitude.

${ }^{13}$ See Advisory Panel (2008) and HMRC (2008) for explicit statements along these lines. 


\section{References}

Advisory Panel on Canada's System of International Taxation (2008): "Enhancing Canada's Tax Advantage." Government of Canada.

Ando, Mitsuyo and Fukunari Kimura (2007): "International Production / Distribution Networks and Domestic Operations in terms of Employment and Corporate Organization: Microdata Analysis of Japanese Firms." REITI Discussion Paper Series 07-E-063.

Arndt, Christian, Claudia M. Buch and Monika Schnitzer (2007): "FDI and Domestic Investment: An Industry-Level View." CEPR Discussion Paper No. DP6464.

Becker, Sascha O. and Marc-Andreas Muendler (2006): "Margins of Multinational Labor Substitution." UCSD Working Paper 2006-04R.

Blinder, Alan (2006): "Offshoring: The Next Industrial Revolution?" Foreign Affairs, 85 (2): 113-128.

Borga, Maria (2006): "Trends in Employment at US Multinational Companies: Evidence from FirmLevel Data." Brookings Trade Forum 2005, The Brookings Institute: 135-164.

Brainard, S. Lael and David A. Riker (1997): "Are U.S. Multinationals Exporting Jobs?" NBER Working Paper No. 5958.

Brainard, S. Lael and David A. Riker (1997): "U.S. Multinationals and Competition from Low-Wage Countries." NBER Working Paper No. 5959.

Castellani, Davide, Anne-Celia Disdier and Giorgio B. Navaretti (2006): "How Does Investment in Cheap Labour Countries Affect Performance at Home? France and Italy." CEPR Discussion Paper No. 5765.

Castellani, Davide and Giorgio B. Navaretti (2003): "Investment Abroad and Performance at Home: Evidence from Italian Multinationals." CEPR Discussion Paper No. 4284.

Caves, Richard E. (1996): Multinational Enterprise and Economic Analysis (Cambridge, U.K.: Cambridge U. Press).

Chor, Davin (2009): "Subsidies for FDI: Implications from a Model with Heterogeneous Firms." Journal of International Economics (forthcoming).

Davies, Ronald and Carsten Eckel (2009): "Tax Competition for Heterogeneous Firms with Endogenous Entry," forthcoming in American Economic Journal: Economic Policy.

Desai, Mihir A. (2009): "The Decentering of the Global Firm," forthcoming in World Economy.

Desai, Mihir A., C. Fritz Foley and James R. Hines Jr. (2009): "Domestic Effects of the Foreign Activities of Multinationals." American Economic Journal: Economic Policy, 1 (1): 181-203. 
Desai, Mihir A., C. Fritz Foley and James R. Hines Jr. (2005a): "Foreign Direct Investment and the Domestic Capital Stock." American Economic Review, 95 (2): 33-38.

Desai, Mihir A. and James R. Hines Jr. (2003): "Evaluating International Tax Reform." National Tax Journal, 56 (3): 487-502.

Desai, Mihir A. and James R. Hines Jr. (2004): "Old Rules and New Realities: Corporate Tax Policy in a Global Setting." National Tax Journal, 57 (4): 937-960.

Egger, Peter and Michael Pfaffermayr (2003): "The Counterfactual to Investing Abroad: An Endogenous Treatment Approach of Foreign Affiliate Activity." University of Innsbruck, Institute of Public Finance.

Feldstein, Martin (1995): "The Effects of Outbound Foreign Direct Investment on the Domestic Capital Stock." The Effects of Taxation on Multinational Corporations. Ed. Martin Feldstein, James R. Hines Jr. and R. Glenn Hubbard. University of Chicago Press: 43-63.

Gordon, Roger and James R. Hines Jr. (2002) "International Taxation" in Alan J. Auerbach and Martin Feldstein eds Handbook of Public Economics, vol 4 (Amsterdam: North Holland, 2002) 1935-1995.

Harrison, Ann and Margaret McMillan (2008): "Offshoring Jobs? Multinationals and US Manufacturing Employment." International Policy Center, the University of Michigan.

Helpman, Elhanan, Mark Melitz and Stephen Yeaple (2004): "Export Versus FDI with Heterogeneous Firms." American Economic Review, 94 (1): 300-316.

Hines, James R. (2008): "Reconsidering the Taxation of Foreign Income." Tax Law Review (forthcoming).

Hizjen, Alexander, Sebastian Jean and Thierry Mayer (2006): "The Effects at Home of Initiating Production Abroad: Evidence from Matched French Firms." CEPII, mimeo.

HM Revenues \& Customs, and HM Treasury (2008): "Taxation of the Foreign Profits of Companies: Draft Provisions." Government of the United Kingdom.

Jones, Ronald W. (1967) "International capital movements and the theory of tariffs and trade," Quarterly Journal of Economics 81 1-38.

Kemp, Murray (1966) "The gain from international trade and investment: A neo-Heckscher-Ohlin approach," American Economic Review 56, 788-809.

Kleinert, Jörn and Farid Toubal (2009). "The Impact of Locating Production Abroad on Activities at Home: Evidence from German Firm-Level Data." Review of World Economics (forthcoming). 
Lucas, Robert (1990): "Why doesn't Capital Flow from Rich to Poor Countries?" American Economic Review, 80: 92-96.

Mataloni, Jr., Raymond J. and Daniel R. Yorgason (2006), "Operations of US Multinational Companies: Preliminary Results from the 2004 Benchmark Survey." Survey of Current Business, Bureau of Economic Analysis.

Melitz, Marc J. (2009): "International Trade and Heterogeneous Firms." New Palgrave Dictionary of Economics, 2 $2^{\text {nd }}$ Edition (forthcoming).

Musgrave, Peggy B. (1969). United States Taxation of Foreign Investment Income: Issues and Arguments. International Tax Program, Harvard Law School.

Navaretti, Giorgio B. and Anthony J. Venables (2004). Multinational Firms in a World Economy. Princeton University Press.

Pricewaterhouse Coopers (2008): "Newsalert: International Tax Services - Asia Pacific Tax."

Scheve, Kenneth and Matthew J. Slaughter (2006): "Public Opinion, International Economic Integration, and the Welfare State." Globalization and Egalitarian Redistribution. Ed. Pranab Bardhan, Samuel Bowles, and Michael Wallerstein. Princeton University Press.

Simpson, Helen (2008): "How does overseas investment affect activity at home?" The Institute for Fiscal Studies.

Yeaple, Stephen R. (2008): "Firm Heterogeneity and the Structure of US Multinational Activity: An Empirical Analysis." NBER Working Paper No. 14072. 


\section{Figure 1: Foreign Direct Investment Position \& Domestic Manufacturing Employment,}

\section{6-2007}

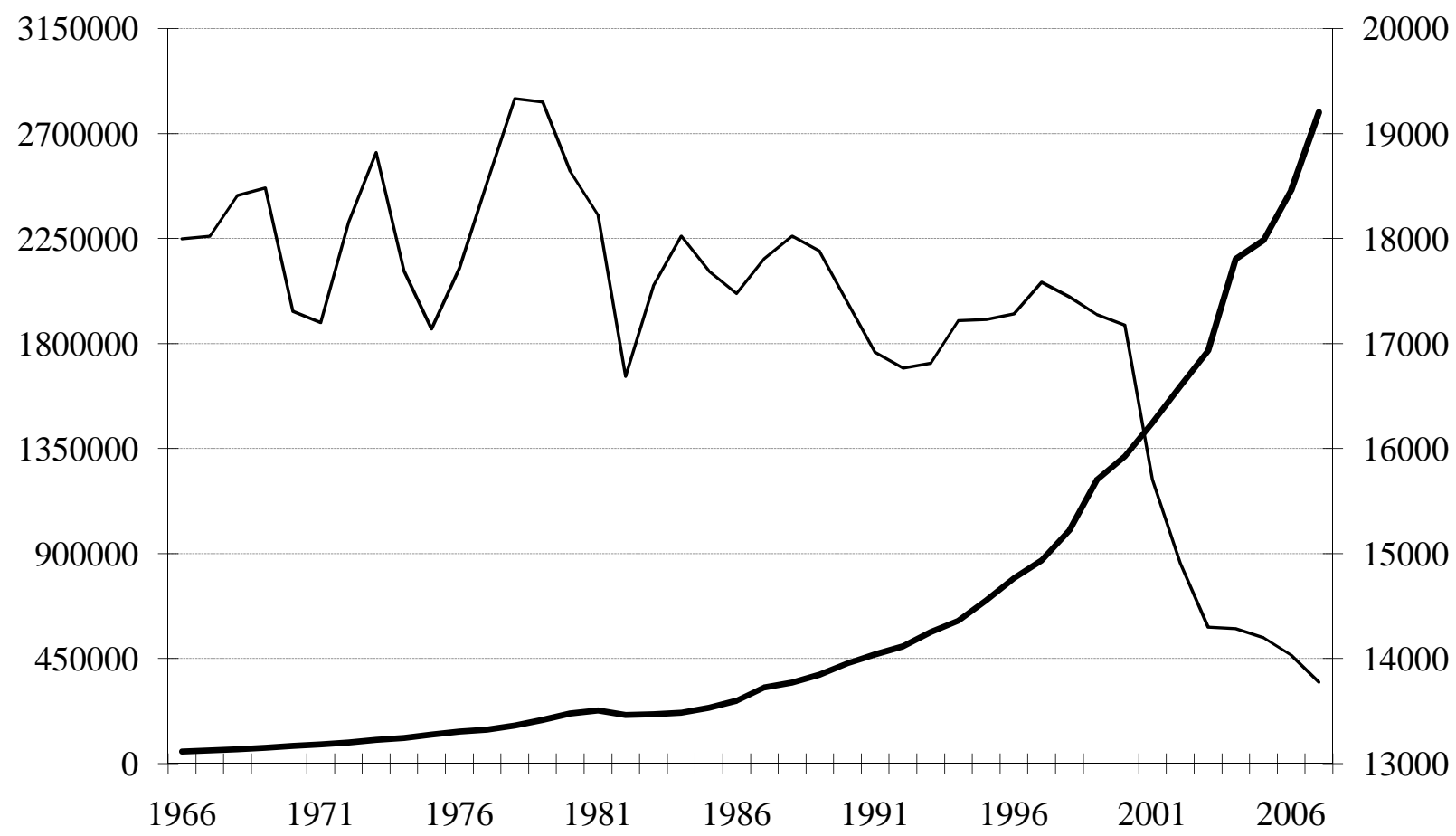

—Direct Investment Position — Total Domestic Manufacturing Employment

Note: The horizontal axis charts years, from 1966 until 2006. The left vertical axis measures the aggregate direct investment position of US firms for that year, in millions of dollars. Data is measured on a historical cost basis, and comes from the Bureau of Economic Analysis's section on International Economic Accounts. Prior to 2006, this data is measured net of withholding taxes, while data for 2006 and 2007 is measured gross of withholding taxes. The right vertical axis measures the aggregate number of workers employed domestically in manufacturing jobs that year, in thousands of workers. Data comes from the Bureau of Labor Statistics. 
Figure 2a: Public Perception of Overseas Employment

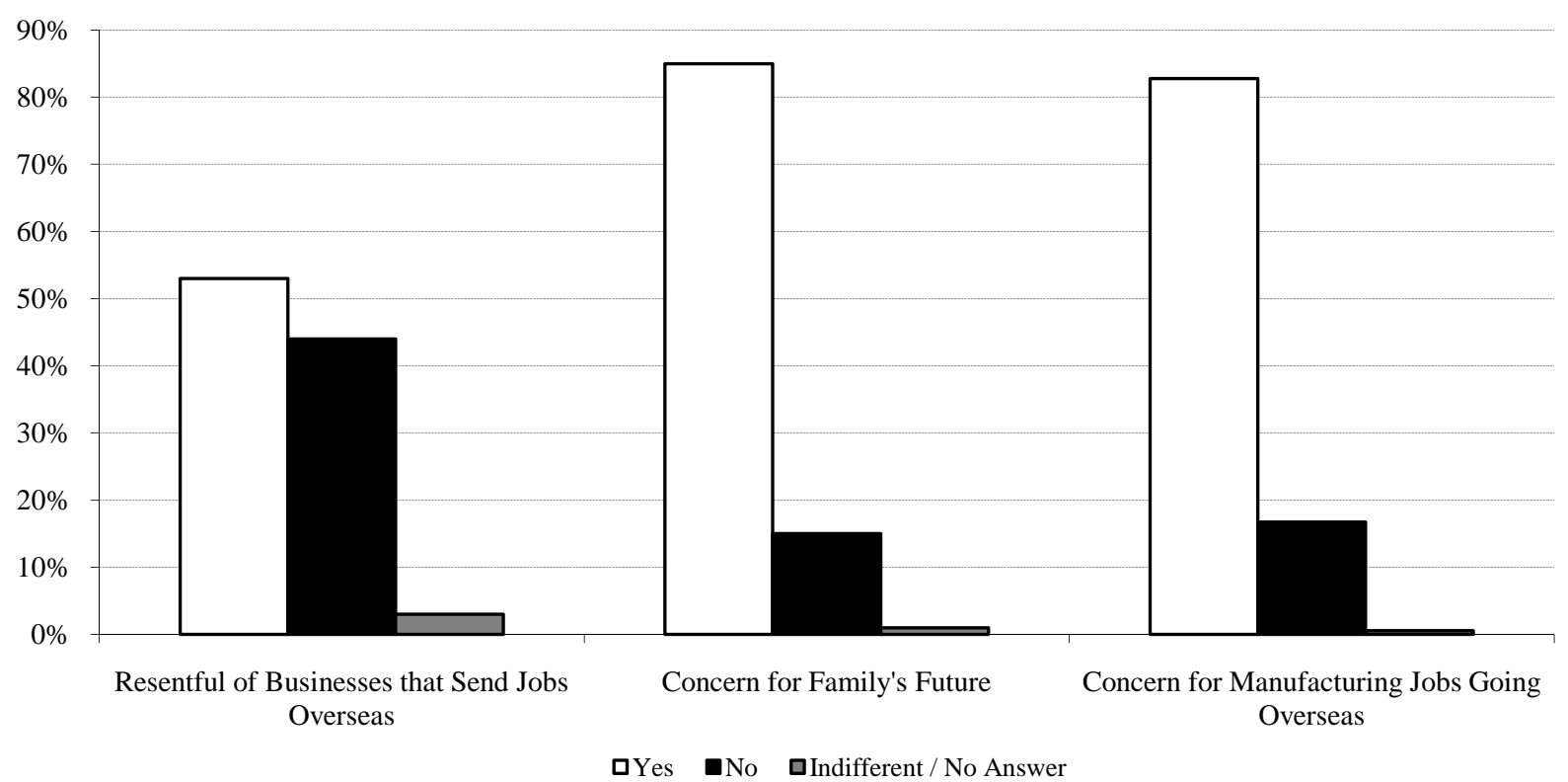

Note: Each category on the horizontal axis represents a different and independent poll. "Resentful of Businesses that Send Jobs Overseas" refers to a Harris Interactive phone poll conducted in 2004 of 772 national adults. Respondents were told, "Are you resentful of businesses that send jobs overseas?" Categories on the graph are the same as response categories for the poll. "Concern for Family's Future" refers to a Penn, Schoen \& Berland Associates phone poll conducted in 2008 of 2008 national likely voters. Respondents were told, "Thinking of you and your family's economic security, how worried are you about each of the following?...Outsourcing of American jobs to other countries." "Yes" is defined here as "Very worried / fairly worried / somewhat worried," and "No" is defined here as "Not at all worried." "Concern for Manufacturing Jobs Going Overseas" refers to a Gallup phone poll conducted in 2008 of 2020 national likely voters. Respondents were told, "Please tell me whether you are worried or not worried about each of the following. How about -- US manufacturing jobs going overseas?" "Yes" is defined here as "Worried" while No is defined here as "Not Worried."

\section{Figure 2b: Public Perception of Government Response to Jobs Going Overseas}

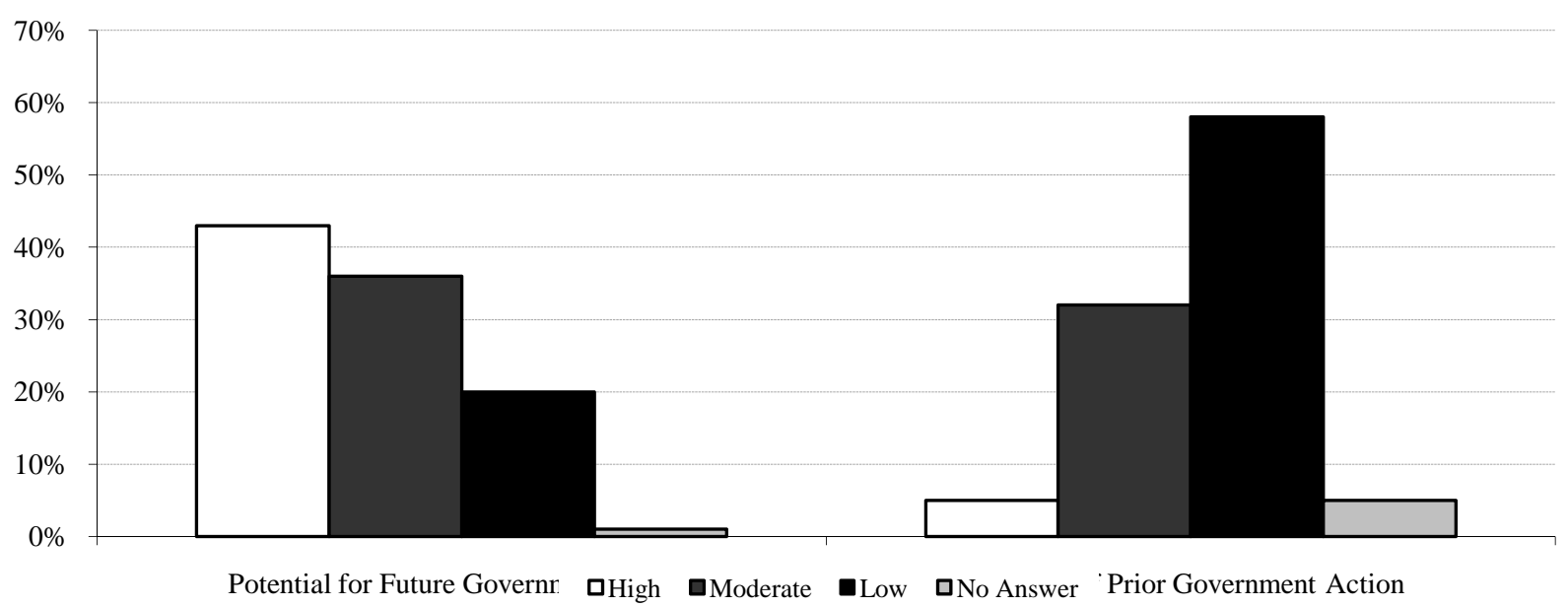

Note: Each category on the horizontal axis represents a different and independent poll. "Potential for Future Government Action" refers to a Public Agenda Foundation phone poll conducted in 2008 of 1006 national adults. Respondents were told, "Is the following something our government can do a lot about, something about, or not much about?...Preventing jobs from going overseas." "High" is defined as "A lot," "Moderate" is defined as "Something," and "Low" is defined as "Not much." "Success of Prior Government Action" refers to a Public Agenda Foundation phone poll conducted in 2008 of 1006 national adults.

Respondents were told, "What grade would you give the United States when it comes to achieving the following goals?...Protecting American jobs from moving overseas." "High" is defined as "A," "Moderate" is defined as "B / C," and "Low" is defined as "D / F." 
Figure 3: The Evolution of Foreign Exposures for American Investors, 1976-2007

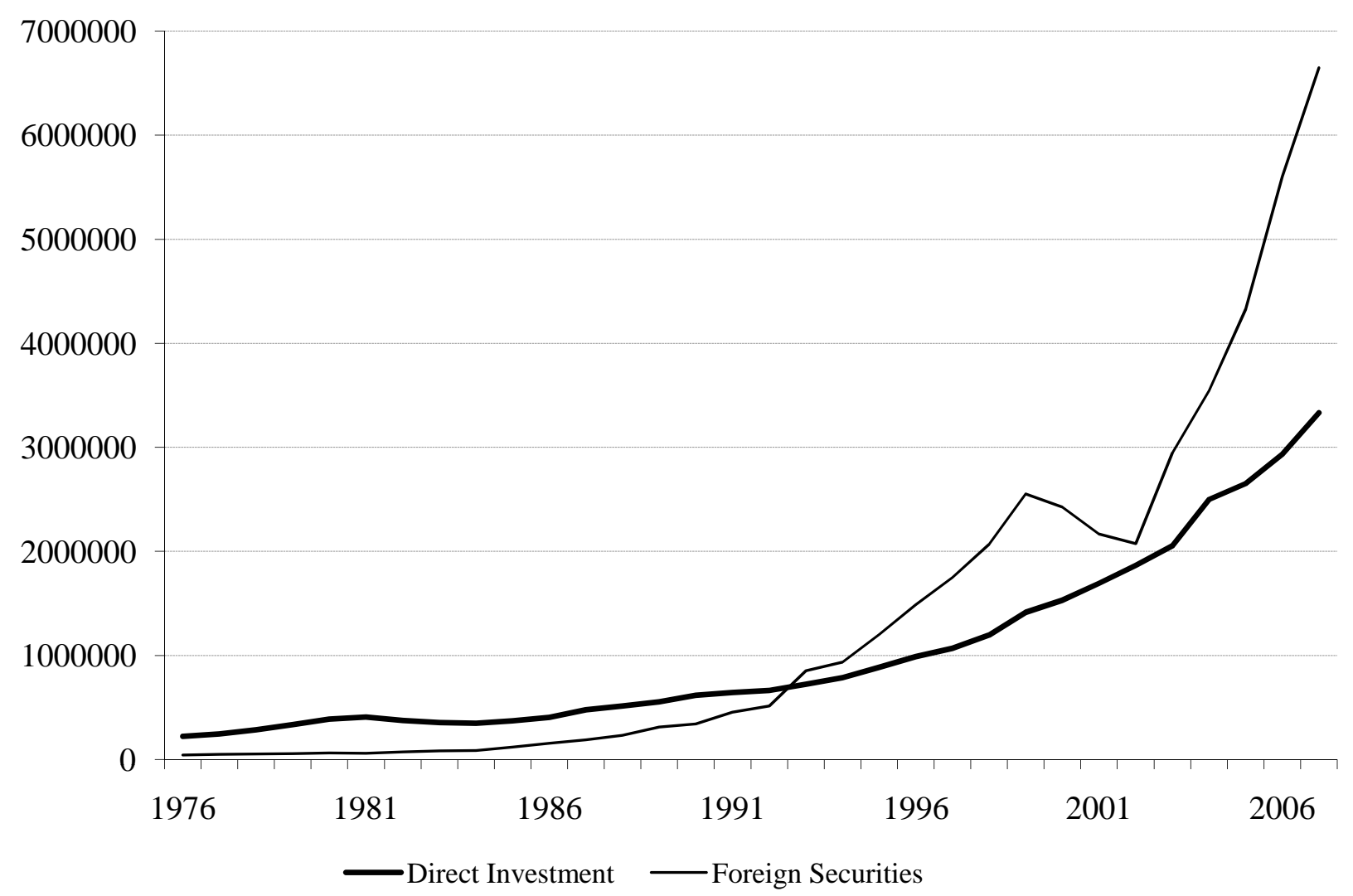

Note: The horizontal axis charts years, from 1976 until 2007. The vertical axis measures the aggregate level of direct investment or foreign securities held by all US firms for that year, in millions of dollars. Data comes from the Bureau of Economic Analysis's section on International Economic Accounts, and all data except 2007 has been revised. Direct investment is measured on a current cost basis. Foreign securities is comprised of both foreign bonds and foreign corporate stocks. Neither direct investment nor foreign securities includes miscellaneous US claims on unaffiliated foreigners, nor does it include miscellaneous claims by US banks. 


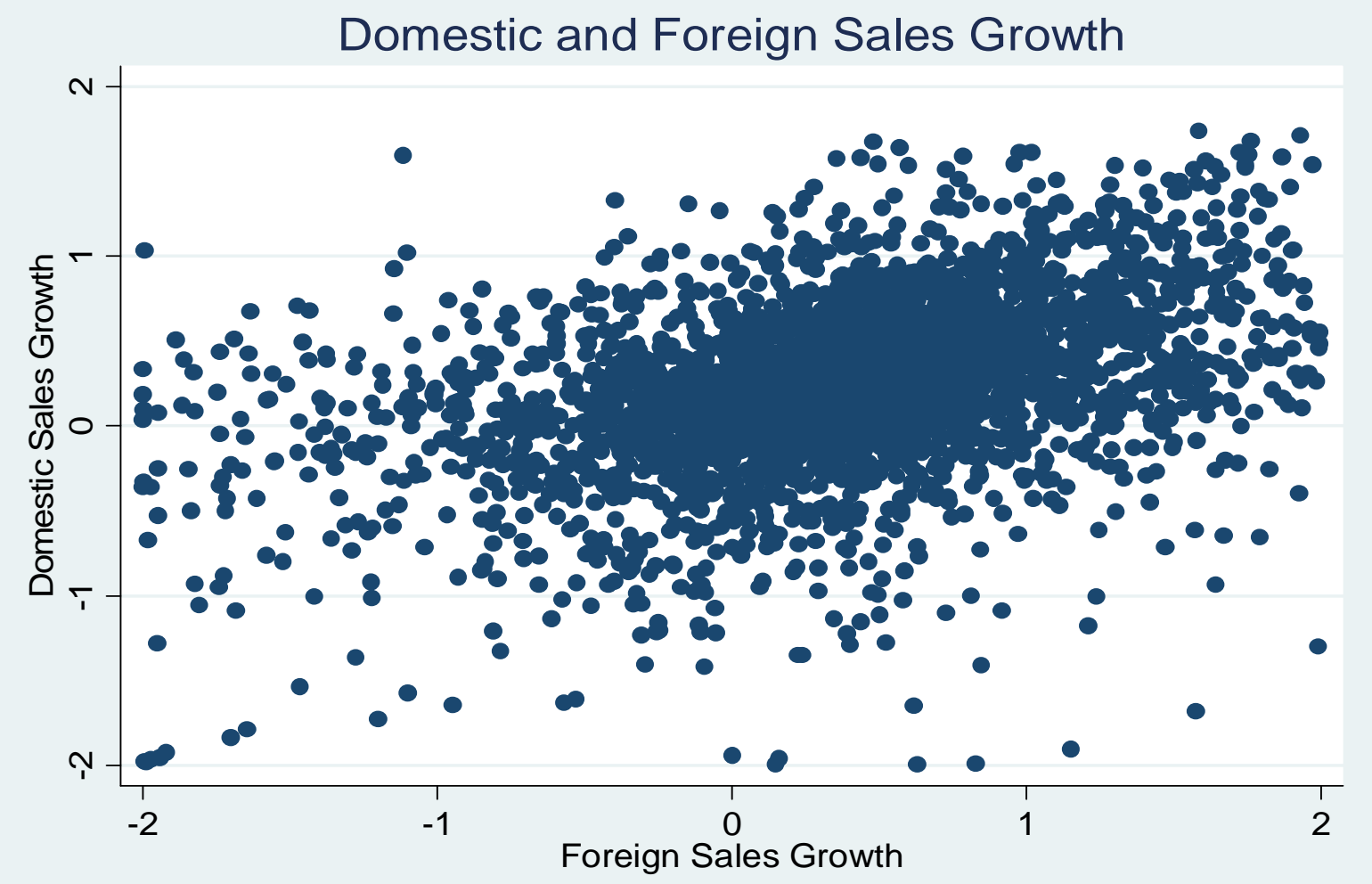

Note: The vertical and horizontal axes of the figure measure growth rates of domestic sales and foreign sales. Growth rates are defined as ratios of changes in sales to the average of beginning and ending period values. Each observation is a single multinational firm between two benchmark years, the benchmark years consisting of 1982, 1989, 1994, 1999, and 2004). 
Figure 5: Domestic \& Foreign Growth of Multinational Firms, 1983-2006
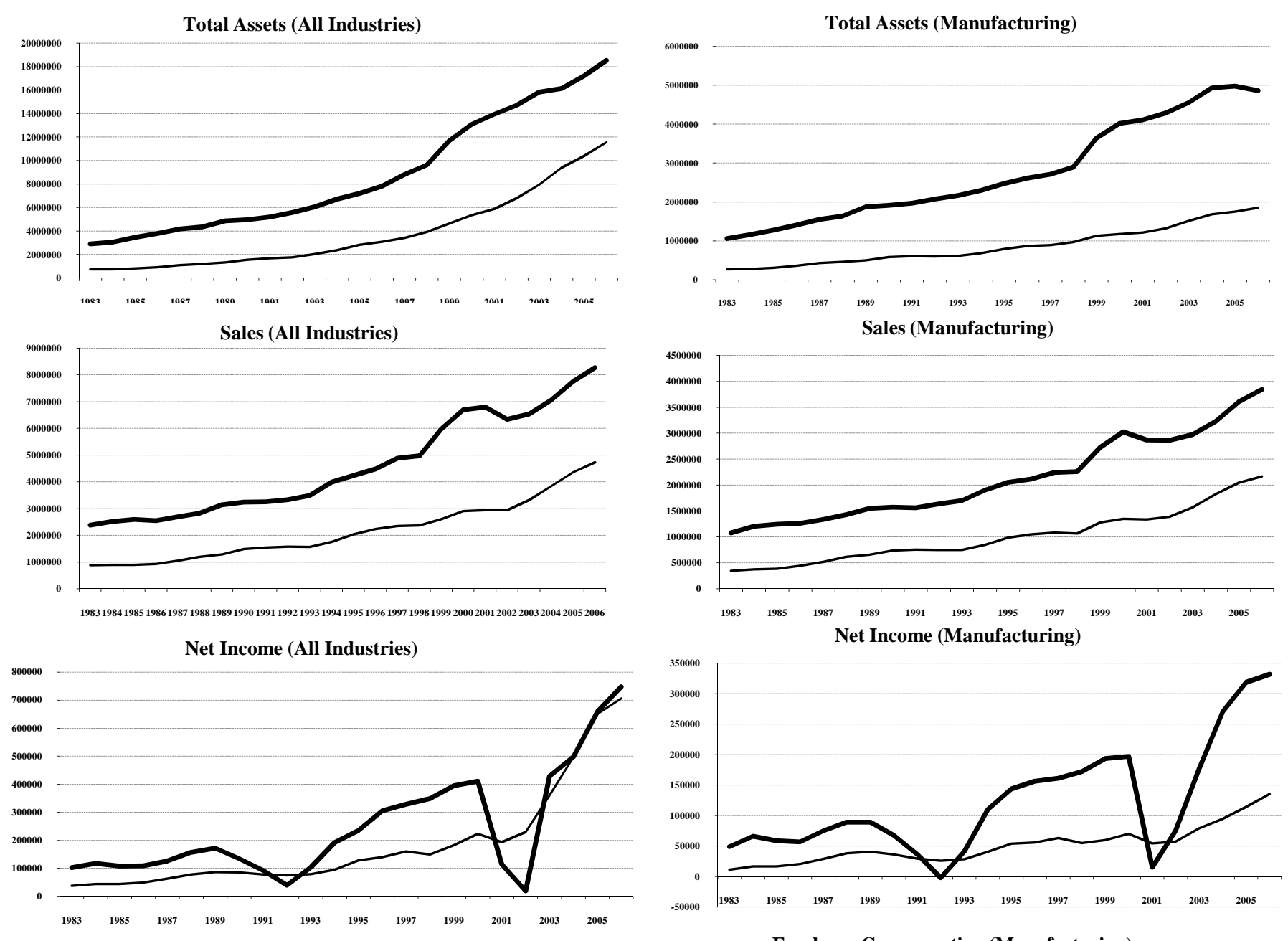

Employee Compensation (All Industries)

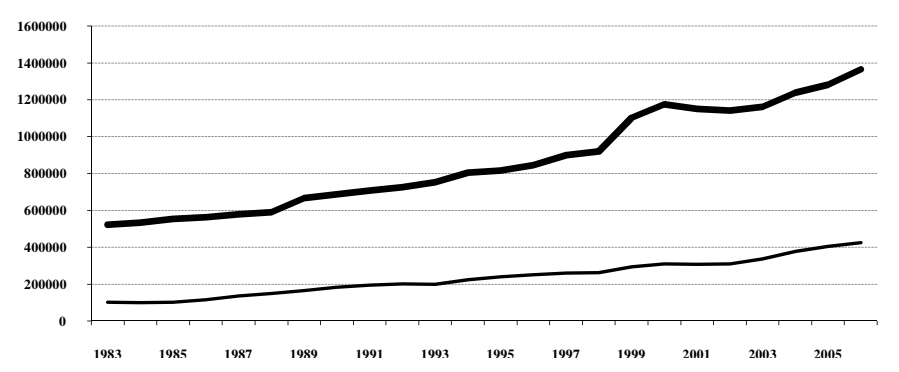

Employee Compensation (Manufacturing)
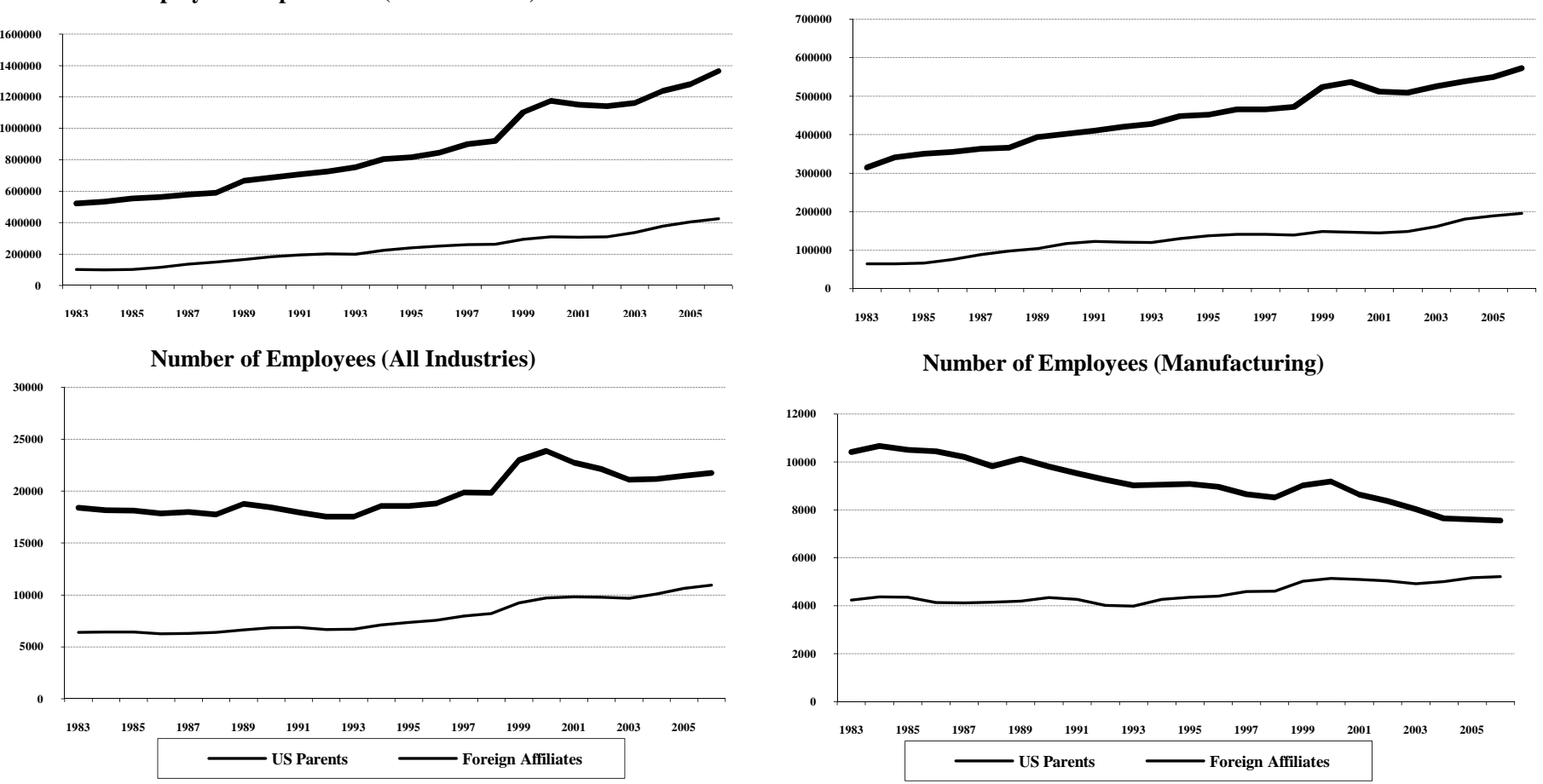

Note: The horizontal axis charts years, from 1983 until 2006. The vertical axis measures the aggregate levels of total assets, sales, net income, employee compensation and number of employees for US multinationals for the respective year. All measurements are in millions of dollars, except number of employees, which is measured in thousands of employees. Data comes from the Bureau of Economic Analysis's section on International Economic Accounts. Data for US parents refers to operations conducted by US multinational firms that take place within the bounds of the US, while data for foreign affiliates refers to operations conducted by US multinational firms and their affiliates outside of the US. 
Figure 6: Multinational Employment: All Industries \& Manufacturing, 1983-2006

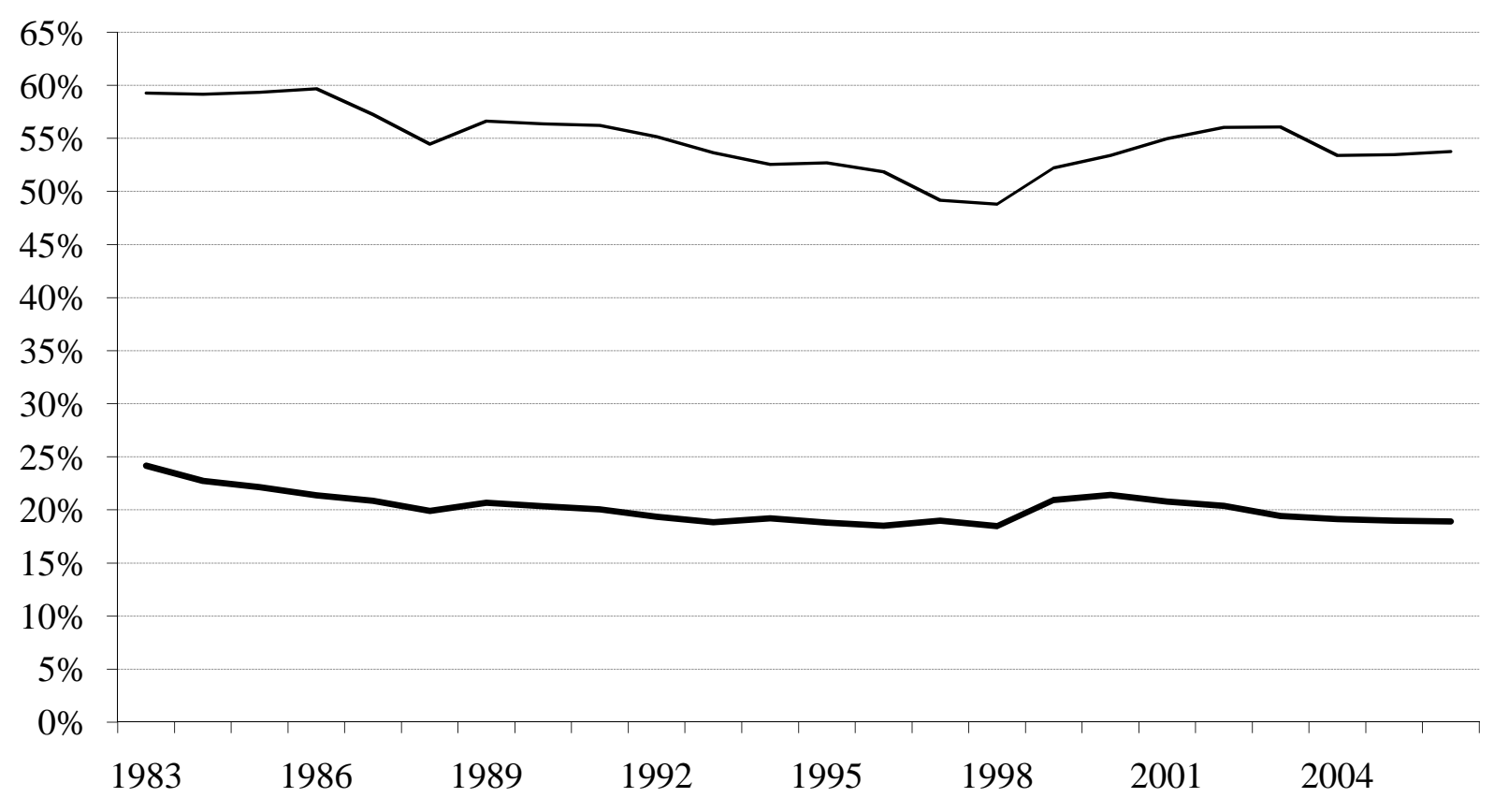

- Percentage of Total Private Employment attributed to Multinational Firms

— Percentage of Manufacturing Private Employment attributed to Multinational Firms

Note: The horizontal axis charts years, from 1983 until 2006. The vertical axis measures the percentage of total private employment or manufacturing private employment provided by multinational firms. Data on multinational firm employment comes from the Bureau of Economic Analysis's section on International Economic Accounts. Data on total private and total manufacturing employment comes from the Bureau of Labor Statistics. 
Figure 7a: Percentage of Skilled Employees in Domestic Operations of US Multinationals, 2004-2006

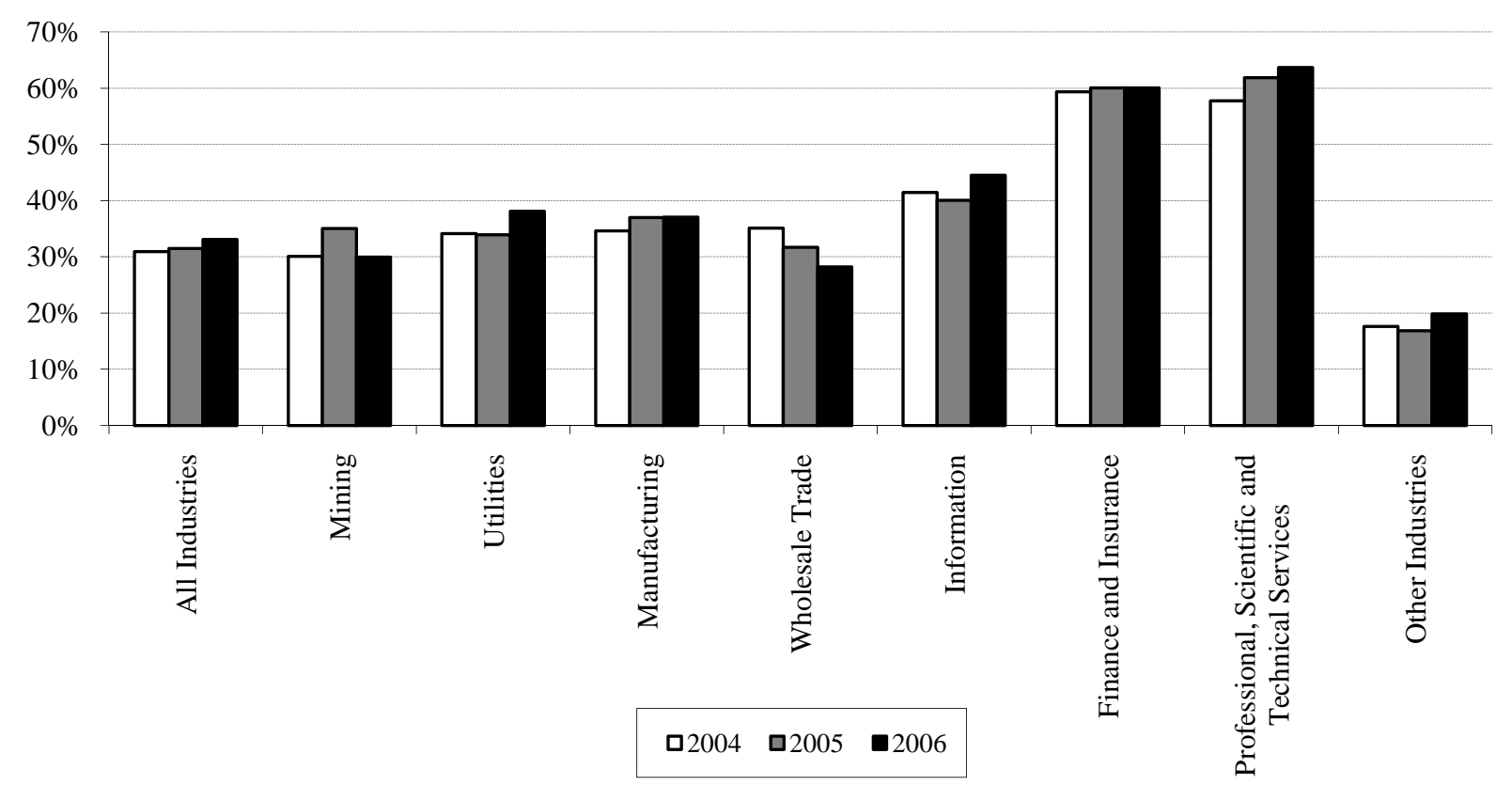

Note: The horizontal axis charts industry classifications, as defined by the Bureau of Economic Analysis. The vertical axis measures the percentage of total domestic employment by US multinationals occupied by those in managerial, technical or professional roles. Observations are made by industry, and by year, from 2004 through 2006. Data comes from the Bureau of Economic Analysis's section on International Economic Accounts.

Figure 7b: Percentage of Skilled Employees in Foreign Operations of Majority-Owned Foreign Affiliates, 2004-2006

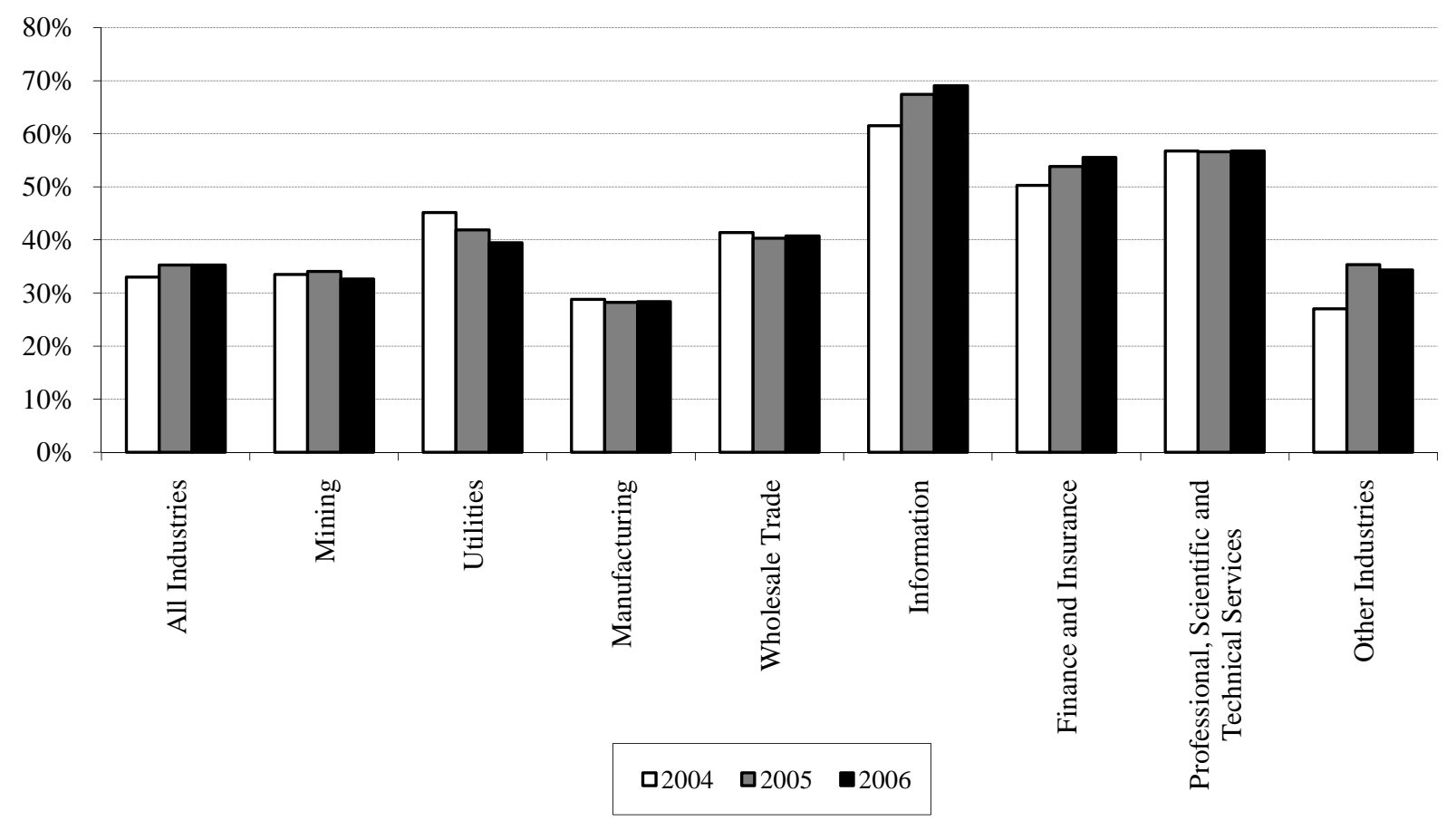

Note: The horizontal axis charts industry classifications, as defined by the Bureau of Economic Analysis. The vertical axis measures the percentage of total foreign employment by majority-owned foreign affiliates occupied by those in managerial, technical or professional roles. Majority-owned foreign affiliates are defined as foreign companies in which $50 \%$ or more of ownership is held by US multinationals. Observations are made by industry, and by year, from 2004 through 2006. Data comes from the Bureau of Economic Analysis's section on International Economic Accounts. 